\title{
Make like a man: \\ the demands of creative work, gender and the management of everyday life
}

\author{
Bettina-Johanna Krings \\ Bettina-Johanna Krings is a senior researcher at the Institute for \\ Technology Assessment and Systems Analysis (ITAS) Forschungs- \\ zentrum at the University of Karlsruhe in Germany.
}

\begin{abstract}
Drawing on a study in the multimedia sector in Stuttgart, Germany, this paper argues that the living and working conditions of women have adapted strongly to the traditional breadwinner concept and that this change has major consequences for general social and cultural development. The study concludes that a historical shift from 'maternal spaces' to the breadwinner model is a sign of deep changes in the reproductive sphere. It analyses the temporal organisation of work-life balance and finds that, although women have gained access to some highly-skilled positions in the labour market which have granted them new forms of autonomy and independence, they have also been exposed to new forms of stress. These preșsures are experienced in a range of different ways both by childless women and those with children, leading to a variety of strategies for managing daily life, each of which entails some losses, as well as gains. Although a critique of the modernisation of working cultures has been opened up, this paper argues that in order to explain the societal impacts of these changes there is a need for further exploration of both the perception and the quality of the losses experienced by women in these change processes.
\end{abstract}

This paper draws on the results of a study of living and working conditions in the multimedia sector in the Stuttgart region of Germany, carried out by the Institute for Technology Assessment and Systems Analysis (ITAS) on behalf of the Baden-Württemberg Ministry of Social Matters, completed in $2003^{1}$. The study aimed to evaluate the changes in this sector from a gender theory perspective.

Initially, three assumptions were made. The first was that changes in the structure of work in this sector, which employs a high proportion of women, would reduce the social pressure on women trying to balance the demands of job and family. The second was that, because working conditions in this sector appeared to be 'knowledgemarked' (Funder 2005, Priddat 2001) rather than 'gender-marked'2, the increased importance of knowledge as a production factor would have a compensatory impact on gender relations within the workplace, reducing gender segregation. The third assumption was that the 'work anytime, anywhere' hype surrounding the new tech-

1 Cf. Krings, B.-J.: Wandel der Arbeits- und Lebensbedingungen im Multimediabereich aus der Genderperspektive, Wissenschaftliche Berichte FZKA 6892, Karlsruhe 2003.

2 In other words, the division of work was not so much based on a traditional pattern of gender segregation as on a functional separation of tasks based on specific skill-sets. 
nologies would create opportunities for workers to reorganise their work flexibly in time and space under their own control.

All these assumptions were confirmed to some extent by the study. However there was no evidence of the development of new models of work or of changes in temporal or spatial flexibility. On the contrary, the pressure of the demands of their work had obliged most of the women to develop individual action strategies which overspilled into the private sphere ${ }^{3}$. It was also noteworthy that whilst the daily management of the conflicting demands of work and home life played a central role in the working lives of women in the multimedia sector, for men there had been little significant change. An important methodological tool used in analysing these strategies was the German concept of Allgemeine Lebensführung. This can be loosely translated into English as 'individual conduct of life' or 'design of life' or 'life plan' but its meaning encompasses not only how personal behaviour and lifestyle may be objectively described but also how this life is subjectively constructed. For conceptual clarity, the word (which is defined more fully below) has been left in its original German in this paper.

The results of the study add weight to the thesis that working conditions in this sector have a strong impact on the Allgemeine Lebensführung. of women. The decision whether or not to start a family is only one example of this. Individual strategies can be considered as a rationalisation of the whole of daily life. Job, family, partnership and individual personal needs all have to be managed in a highly rational and functional way. The cumulative effect of these individual strategies seems likely to bring about unexpected consequences at a societal level.

After looking at the specific work conditions in the multimedia sector, this paper goes on to outline the theoretical and methodical framework of the study before presenting a classification of the action strategies of the men and women who were interviewed and finally discussing some of the implications of the results for further research.

\section{Women working in the multimedia sector}

The study drew strongly on a previous study of the multimedia sector carried out in the same region by Gerhard Fuchs and Hans-Georg Wolf4. The term 'multimedia' is used broadly, to refer not only to particular technologies or products, but to all those parts of the IT sector that are involved in producing the knowledge and broad applications incorporated into multimedia products and processes. Besides the technical constituents of digital media, such as sound, film, graphics, and text, it also encompasses associated activities involved in 'networking, integration, and interactivity'(Fuchs \& Wolf 2000:11).

3 In industrial sociology, the blurring of the boundaries between work and life has generated a large literature (see Voß 1998, Minssen 1999, Kratzer 2003). Some recent studies have suggested that this blurring can be noted on all social levels and in temporal, spatial and gender-specific dimensions (survey: Gottschall \& Voß 2005). $4 \quad$ The project Regional Renewal by Multimedia (REMM) by the Academy for Technology Assessment in Baden-Württemberg, completed in 1997, carried out a range of surveys in order to find out the conditions under which regional multimedia industry clusters are established in the region and how this development is supported by regional actors (cf. Fuchs \&Wolf 1998a, 2000). 
The German state of Baden-Württemberg, in which Stuttgart lies ${ }^{5}$, has a broad representation of employers involved in both the production and the application of information technologies. Fuchs and Wolf have divided the sector into three categories. The core subsector comprises firms, which are directly involved in the production of multimedia applications. Examples of this are internet companies or producers of CD-ROM. The second group, referred to as the first periphery, involves the production of information and communication technologies and the generation of content. This is a large group and includes telecommunications, advertising, software production and graphic design firms. Some traditional industries (such as publishing) also belong to this group. The third group, referred to as the second periphery includes most other sectors, including the public sector, there being almost no sectors in the economy that do not use some application of information and communication technologies (Fuchs \& Wolf 2000:12).

Fuchs and Wolf show that the boundaries between these subsectors are open; information and communication technologies are used as multifunctional technologies across all economic sectors and therefore the term 'multimedia' cannot be used with any precision to define a particular sector.

In Stuttgart, as in Germany as whole, the proportion of women in the core subsector is extremely low, as is generally the case in informatics in Germany. ${ }^{6}$ In the first periphery, however, the proportion of female employees is much higher, especially in advertising, graphic design and media content. With a few prominent exceptions, in the Stuttgart region this subsector is characterised by a large number of small and medium sized firms ${ }^{7}$ which, under the pressure of technological change, have undergone a series of changes in working conditions over the last fifteen years. This organisational restructuring has, however, introduced forms of temporal flexibility and project-oriented as well as team-oriented work, which has made them particularly attractive for women.

During the 1980s and 1990s a large research literature on working conditions in the IT sector ${ }^{8}$ in Germany concluded that it would become a major employer of skilled women (Boß \&Roth 1992). There were several reasons for this (Boes \& Trinks 2005:283). First, the switch to a strong customer orientation changes core competences, with social competences and teamwork (thought to be more feminine in character) gaining in importance, whilst the number of purely technical tasks (more likely to be found amongst men) decreases in many jobs. Second, organisational structures, such as flat hierarchies, informalised career paths, and open enterprise cultures offer increased scope for individual and creative actions and, hence, improved professional opportunities for women (whose career paths have traditionally been regarded as less continuous than men's). Third, the promotion of women is often highlighted in corporate strategies, which emphasise the sector's needs for performance, creativity, and qualifications and push for the integration of women, giving a high profile to issues likework-life balance and the promotion of

5 In the state of Baden-Württemberg the Stuttgart region (aprox. 3, 52 firms per 100,000 inhabitants) has the highest density of firms in the multimedia sector, mostly located in urban areas (see Fuchs \&Wolf 2000:16).

6 The extremely low proportion of women in the core subsector of the multimedia sector is remarkable. Even young girls show a low interest in studying technologies, informatics and natural sciences (Zwick \& Renn 2000).

7 A study shows that over 70 per cent of firms in the region have less than 20 employees (Menez et al. 2001). 
women. Finally, there are significant numbers of women in managerial positions in this sector, especially in the middle levels where the number of women with responsibility for personnel is above the average across the whole economy (Funder 2005).

The assumption was that these conditions would increase the employment of women in this sector. However the employment rates of women have actually decreased slightly in recent years, in absolute terms. But, unlike other knowledge-based sectors, multimedia still offers attractive work opportunities to women who are attracted to a flexible and creative working environment.

After the 2000 stock exchange crash, the multimedia sector in the region entered a phase of economic crisis and stagnation. Stuttgart, with its high concentration of multimedia firms, was hit particularly hard, especially the small firms. The drop in sales resulting from the general decline of the local economy heightened competitiveness, which led to a dramatic fall in product prices, especially for software companies. Economic decline shook the prevailing enterprise culture and put downward pressure on the working conditions, with the scrapping of a number of social integration measures that had been introduced during the 1990s. From the employers' point of view, the sector was undergoing a process of 'normalisation' (Boes \& Trinks 2005:288).

\section{The methodological and theoretical approach of the study}

Methodologically the study was based on the concept of the Allägliche Lebensführung developed in the late 1980s by sociologists at the University of Munich in Germany to analyse how peoples' daily lives both change and are changed by the increasing flexibilisation of organisational patterns (Jurczyk \& Rerrich 1993, 1995). The concept differentiates analytically between the temporal, spatial, rational and emotional aspects of a person's organisational self management in order to analyse how work structures interact with aspects of daily life such as partnerships, family life and social and cultural activities. Individual strategies are regarded as an active system that reveals how work and life are socially constructed in industrialised societies and what temporal, social and emotional resources are available within a society (Voß 1995:34). Because these strategies are formed in reaction to existing frameworks, they cannot be regarded as the simple result of individual agency but must be seen in both their objective and subjective dimensions; and not just as the results of individual psychological disposition but as a sociological reconstruction of societal reality (Oevermann et al. 1978, Wohlrab-Sahr 1993).

The methodological tool used to analyse these strategies for living was the development of typologies that make it possible both to compare and amplify individual perspectives whilst simultaneously putting them together to form a larger picture that can be evaluated in terms of its general structure. Thus both the subjective and objective logics of daily life can be identified separately and compared enabling conclusions to be drawn at a societal level (Wohlrab-Sahr 1993). ${ }^{9}$

These typologies were evaluated from the perspective of gender research which (in contrast with feminist research) focuses primarily on a comparison between men and

9 In order to ensure the comparability between the types, the construction of the case studies was subdivided into common aspects so that general conclusions about changes in working and living conditions could be formulated. 
women (Becker-Schmidt \& Bilden 1995). Because the study found that the tensions and ambiguities within individual Allgemeine Lebensführugn were significantly greater for women than for men, this paper focuses mainly on the contradictions in women's practices of day-to-day life management, especially in adapting to the breadwinner model. The ambiguity of women's' Allgemeine Lebensführung necessitates a clear methodological instrument to analyse the social and cultural changes in the daily organisation of the productive and reproductive spheres to ensure that the researcher's own preconceptions do not influence how the interview material is interpreted (Harding 1990).

Twenty open interviews were conducted with sixteen women and four men aged between 20 and 45 . All worked full time in the multimedia sector, with work ranging from creative activities to management. The sample included people with and without partners and with and without children. Generally it was much more difficult to find women with children than without. The interview questions addressed five broad themes: the work situation; the living situation; strategies of day-to-day organisation and self-management; the problems encountered and costs incurred in the day-to-day organisation of life and values, visions and individual expectations.

The male interviewees formed a comparison group within a sample featuring the different levels of meaning of the female strategies. Although the men showed a generally open minded attitude towards family life, work life balance and future perspectives, they had not concretised this in relation to their own temporal and spatial flexibility and could therefore be said to represent the 'breadwinner model' in their Allgemeine Lebensführung.

\section{Labour as the leitmotif of a subjective lifestyle}

It is characteristic of the multimedia sector that the job is the dominant constitutive element of both male and female Allgemeine Lebensführung In every case, it was work structures that made up the central leitmotif of Allgemeine Lebensführun even amongst women with children. For instance, one respondent who had originally decided to take a 'nursing break' by reducing her working hours for three years after the birth of her son, quickly went back to full-time employment because she could not bring this way of life into line with her concept of herself as a woman. Despite this dominance of work in their lives, individual strategies varied according to family background, individual orientations, and value structures as well as their particular circumstances. No strategy was easy, however. Each one took a heavy toll on both psychic and material resources to make it work.

In the interpretation of the interviews, a four-fold typology emerged. These four ideal types can be found in all the case studies in various forms and represent prototypes for the management of work and life. The distinction between the types is constructive, since there are parallels and overlaps between all these Allgemeine Lebensführung. These types have been named 'Control,' 'Discipline', 'Individual Freedom'and 'Stringency'. The first three of these, and especially 'individual freedom', have also been identified in other comparable studies carried out in different working contexts (cf. Wohlrab-Sahr 1993, Behringer 1998, Manske 2003). 


\section{Control}

The control type subjects the rhythm of general life entirely to the structures of work. The prototype of this action strategy is a female interviewee, who identifies strongly with her company and work conditions ${ }^{10}$ and who had decided at an early stage to pursue a successful career and not to have children. She reduces the risk of having to deal with unexpected contingencies to a minimum by rigid control strategies.

'It's a case of "either/or", I do not think that you can love your work and still have children, to be honest. I believe that one thing always suffers and if so, I wanted to make the right choice. Either I want to be a real mother or I want to commit myself to work and as I think that I am not really predestined for being a mother, it was clear relatively early ... that my priority lies somewhere else.'

Deciding early on that she was not a born mother, this respondent chose to concentrate fully on her job. She made this clear to her partner before they married; 'this was clear before anything else was clear', and now he sees 'how much stress a child causes'. Although she knows that this is an 'egotistic' attitude, she feels she contributes to supporting families that 'give birth to children' through her 'high taxes'.

This respondent works in a very structured manner. Trained as a saleswoman, she describes how familiar the company's processes are to her and how she has them 'under control'. Her work is often very hectic, and one of the reasons she likes to work in the evening is that it is quiet at this time when customers do not call and she can work calmly. She speaks of the 'terror of availability' which in her opinion has increased considerably with email.

She thinks that lack of time is the biggest problem she faces. In her job, she is constantly confronted with stress and time pressure which she tries to circumvent by extending her working hours. Outside work, she tries to 'reduce the stress' by doing sports and refloxology massage with a colleague at least once a week. She knows that she must take care of herself if she wishes to spend her remaining working time in an acceptable state of health so she tries to avoid always giving her job top priority. But stress is 'always there', including at home, where there is always 'something to iron and to wash and to clean'.

This respondent has always been the decision-maker in her private life, where it is important to her to stay in control of the household and her social environment. She concedes that she is rather 'dogged' in household matters, much more 'materialistic' than her partner, and with a need to be 'perfect'. As a result, she has more 'problems' than he has. But, she says, they both try to negotiate compromises.

In her life, this respondent is stressed to a very high degree. Her physical and psychic well-being and her private life are affected by her stress at work. She knows this and tries to counteract it pragmatically, with more or less success. Her inner state, however, is mostly 'nervous' and 'tense'. Still, her stress in the job appears to be at a fixed level that she cannot and does not seem to wish to change. Nevertheless, she says she feels 'satisfied in her job' and 'happy in her partnership'.

10 This respondent was a 36-year old woman (I 16), married with no children, working as an industrial sales representative in a marketing agency (cf. Sample Krings 2003). 
Although she reflects very little about her life, she sometimes admits to wondering whether she is repeating her father's life pattern without seeing any possible way of changing this.

'I cannot tell you, I don't know whether I think about it ... Of course, I sometimes

think about whether it is really my pattern to repeat what my father did. He

grafted away all his life and died at the age of 50. Of course, I have to say

clearly no, but I do not know, how I can avoid it. It could only be avoided by working in another sector ...'

She knows that a large part of her 'self-confidence and personal happiness' are derived from her work, and she does not want to and cannot do without it but it nevertheless does not give her a sense of fulfilment. Nevertheless, the creative part of her work makes her feel very happy and she enjoys the feeling of completing a project successfully. She looks forward to material security and a guaranteed income in her old age and she is realistic and matter-of-fact in realising that this means that she will have to work for a very long time.

Here, the strategy of control creates a rigid framework of values and routines that protects and structures her way of life and her security. She reacts inflexibly and in a closed manner to any unforeseeable event. She lives with an obsessive feeling of responsibility from which she cannot escape. She has internalised the traditionally 'male' role and oriented her vital processes towards 'control' and 'efficiency'. She is aware of the price she pays - her health, but uses the same efficient strategies to ensure that this too remains under control.

\section{Discipline}

In contrast to the control type, the discipline type tries to remain open to demands from all sides. Although work still plays a dominant role, this type claims to have integrated it with other aspects of life. A woman manager provides an example of this prototype ${ }^{11}$.

Unlike the control type, she perceives the processes of life not as a threat but as a design challenge that necessitates clear decisions and self-discipline in everyday life. Before becoming a mother this respondent worked twelve hours a day with 'at least four evening meetings per week, and also went into her office for several hours on Saturdays and Sundays. Since the birth of her son, she has given up weekend work, but is still working 'more than 100 per cent' (she estimated that she worked 140 per cent of the official working week). This 'unpaid additional work' is done with pleasure, as she 'enjoys working' and work has become part of her identity. This respondent selected her apartment to ensure that she could get to work in less than ten minutes and has fixed the start of her working day to fit in with her family obligations.

This respondent and her husband (who also works full time) have organised their child care: three days a week with a childminder, with a relative standing in on the other working days. There is close contact both with the respondent's parentsin-law and with her own parents.

11 This 39-year old respondent (I 7) works in a management position in an editorial department. She is married, and has a son (cf. Sample Krings 2003). 
This respondent takes prime responsibility for the household but her husband takes care of visits to the shops, dry cleaning and shoe repairer on working days and does most of the laundry. She 'organises' the household, anticipating what work will be needed and delegating parts of it. She also does the weekend shopping, cooking and cleaning of the apartment.

The overall organisation of everyday life is determined very much by the demands of work. Her conception of the job involved a blurring of the two spheres, but she tries to counteract this establishing a strict separation of work and family. She says that she organises family-related tasks so that 'the job does not suffer - this cannot be'. Phone conversations with her husband about the practicalities of household organisation are limited to 'a matter of twenty to thirty seconds'. She avoids longer private calls because they would distract her too much from her work.

Her son is so well adapted to this tightly-organised everyday life that even when he is sick, the time is 'chosen so smartly' that it happens at the weekend or during the holidays. 'Well, I have to knock on wood - one, two, three - he is a very healthy child, and when he has fallen sick this has fortunately been during my holidays or at the weekend, he has ... sometimes, I think he realises it ... it is just (she laughs) it sounds strange, but it is just ... it fits, and so far, no serious accident has occurred. I mean, I have always been able to organise something.'

She considers her marriage to be 'stable'; with serious disputes only occurring when 'everything is about to collapse at home' and the stress of the job takes its toll. She attributes her ability to combine her professional and private lives so well to the quality of their partnership and to her own self-discipline.

Contrasting herself with her own parents, who have their own company and are 'very busy', she says she does not want her child to 'just live alongside' but considers it very important to achieve a harmonisation of job and family. Her idea of being a 'good mother' involves trying to create an 'ideal world' during the time she spends with her son: 'during this short time, these two or three hours in the evening. For her, it is most important that her son feels that his parents are always 'there for him' although she does not have as much time for him as other mothers. She is convinced that he benefits from his parents' lifestyle.

To meet these high demands, her life is characterised by strict discipline, which results in permanent stress of the highest order. Pains she experiences in her back and jaw may well be interpreted as a consequence of her need to 'clench her teeth' and to carry 'loads that are too high'.

She presents herself as a woman who has to 'hold her ground' in life. Her roles as a mother and partner have been subordinated to this conviction which, nevertheless, coexists with traditional value structures expressed in a feeling of responsibility for the wellbeing of those around her. Like the control prototype, she concedes that the job has priority in her life, but she also feels committed to 'female values'. Enormous personal effort is required to meet these exacting standards and her life is only made possible by strong personal discipline, organisation, and integration of the social environment into the planning process. The strategy of disciplining general life is the only means by which continuity between the different areas of life can be achieved.

Sometimes, this respondent dreams of living an entirely different life. 
'I could tell you a dream (she laughs), something I really ... I would like to give up everything in Germany and move to the South of France. But this is something I said ten, fifteen years ago, I always said "this is what I would like to do when I'm fifty". Then I will do this: I will cut all ties and open a little bistro, and do a bit of bed and breakfast (she laughs) ... Yes, because I think that this is something completely different, but whether I will really do so... it is just a vision.'

\section{Individual Freedom}

For the individual freedom type the subjective power of being able to design both one's own life and the social process is the most important priority. For this, work is an absolute necessity to gain access to social resources which are achieved through individual effort rather than social affiliation by birth or gender.

The focus is on the person's own competence and the internal urge to take life actively into her own hands. Her life is characterised by openness, courage, and the ability to plan. This attitude is very frequently found in young people, although our prototype for this type was thirty three years old, a childless freelance graphic designer, living with her partner in a shared apartment ${ }^{12}$.

She organises her time flexibly, at least when she is working directly for own clients (a minority of her contracts) and likes to organise her days freely, doing housework or going for a walk in between work tasks. Her professional workload varies considerably. 'Totally, totally different, sometimes I have to refuse contracts for months and can hardly manage and I work during the weekends and on holidays and so on. But sometimes nobody calls.'

Often the work extends into the evening and weekends. Sometimes she works at her office during the day and then at home in the evening for her 'private customers' where she feels she has to meet their needs in a very flexible and willing manner. Whilst recognising the stress they cause, she regards these pressures as 'normal' and typical of this type of work which she says she can handle because she knows that the stress is always ' limited in time'. For her, this is the big difference between her situation and that of an employee.

She finds it difficult to say no to offers of contracts because she fears that if she does so she will not be asked again, so she tries to meet all demands, saying that her 'pain threshold is very high as far as stress is concerned'.

During the course of their relationship, she and her partner have evolved a flexible division of labour in which individual needs are prioritised, and organisation does not take up much space in her life. She tries actively to resist overly high demands and prefers to spend her free time in private activities saying that 'personal contacts are most important'. She likes eating out and going to the cinema and does sports three times a week but the rhythm is dependent on her work situation. She does not make rigid divisions between work and non-work activities or pursue any specific activities at the weekends, which are also subject to the rhythm of her work.

'No, actually, the weekend... Actually, it's the same as during the week, except, that, when I am booked, I sleep longer at the weekend and go shopping and have

12 The prototype of this action strategy is a 33-year old (I 6) freelance graphic artist without children, who lives with her partner in a shared apartment (cf. Sample Krings 2003:52 ff.). 
a long breakfast and go downtown, but, since I have breaks sometimes, I sometimes also do such things during the week. And then, at the weekend there is no big difference.'

Whilst believing that the challenges in her life are 'in the usual range' she distinguishes between those that are caused by work-related stress and those that are part of the normal processes of life. She tries to handle the former pragmatically, saying that she is able to work well under pressure. For help with the latter she turns to her friends and family, with her father playing an important role. She presents herself as a 'master of the art of living' who has succeeded in developing a successful life plan despite the ups and downs in her life. However she also knows that her independent and flexible life has its price. Although she acquired clear orientations and 'moral conceptions' from her parents, she is trying to free herself from the 'standards, conventions, and education' of her past. She attributes the differences between herself and her parents to the new opportunities offered by modern life:

'Well, they also might have had the possibility, but they simply set other priorities, but they were also under the supervision of their parents and, of course, they experienced other things, such as war, when they were children, and so on, but... God knows, things were different in those days, I mean, they did not think for long about whether they wanted children or not; they married and just had children. I mean, today, the problems are completely different, and probably when you have children you will also ask questions like: when you have children, how will you organise your work?, this was not a question in the past. That's why ... the decision today is not always easy.'

She would not consider giving up her 'freedom', which is the leitmotif of her life and what makes her different from her parents. Her most basic orientation is towards the possibility of saying 'yes or no'.

This respondent regards the changes that have taken place in the gender order as positive because men have been relieved of their economic responsibility and women are able to make independent decisions. She emphasises her individual sphere of responsibility although it is important to her that she and her partner plan their life jointly. She has put off the decision whether to start a family, finding it hard to decide whether to have children which she associates with giving up her autonomy, feeling 'a large uncertainty', because she does not wish to entirely 'dispense with her life' and is afraid that the primary care of the child will 'stick' with her. The lack of models is important here; she does not know any woman who is able to combine both areas in a way that does not forced her to give something up. She does not, however, regard such dilemmas politically, as aspects of gender inequality. On the contrary, for her, everything is a matter of individual decision.

\section{Stringency}

The stringency type is characterised by rationality in general life ${ }^{13}$. Here, the prototype is a male company director. Divorced, with two children from his former marriage, he now

13 This prototype is represented by a male interviewee (interview no. 10), who has founded his own enterprise together with partners, a consulting company for digital communication strategies and technologies. The respondent owns the majority of the enterprise and is its general director. Divorced, he lives with a new partner and has two children from his previous marriage (cf. Sample in Krings 2003:52 ff.). 
lives with a new partner. This respondent is someone who regards self-confidence and competence as crucial for success in life. He has a wide range of responsibilities for the running and strategic development of the company.

'Well, I am so lucky that we entered the market successfully with hardly any preparation. In principle, I am involved in individual projects. But most of my present tasks very, very much focus on the vision of the company. As we have made such a good start that secures us and allows to think further and not only about the daily business, I can leave aside the daily business to a large extent and can care about the vision of the company, the future of the company, and I can initiate the necessary steps.'

Trust and openness are integrated into a stringent concept of work which he expects his employees to share. Compulsory working hours for all employees in the company is from $930 \mathrm{am}$ to $6 \mathrm{pm}$. As a rule, he stops work at $7 \mathrm{pm}$ but may work until $10 \mathrm{pm}$ or later if a project schedule requires it. He does not consider that his position as director puts him in a special position but expects his employees (all of whom work full time) to show equal dedication and identification with the company.

Regarding himself as a 'career changer' he selects his staff on the basis of social skills and human competences rather than formal qualifications, qualities which he thinks he can judge on the basis of his experience and personal judgement.

Since the break-up of his marriage, which he attributes to a neglect of his family, his role as a father has acquired a new importance in his life. With relatively frequent contact with his children (an arrangement he says he has worked hard for), he makes an effort to live a 'piece of everyday life' with them, to take an interest in school matters, to go to parent-teacher conferences, and to be available as a 'contact partner'.

'In fact, it is rather normal. Actually, I'm not the "event person", who looks for high-level experience and where every day, cake is served on the table ... No, it's really normal, they are with me and I read or do something different, and the children also do something.'

However this process is still incomplete. His new partner works full-time. They spend the time with his children together and also go on holidays together and the situation is not easy for either of them and often leads to conflict. He recognises that it is difficult for his partner to accept his children, but thinks that 'many steps' have already been made in a positive direction. Meanwhile, he tries to 'drive on two tracks' and to make time for his relationship with his partner who has asked him to change his gender-specific conception of his role and to take on some household responsibilities and play a more active role in the partnership. He has ventured on these new processes and considers himself to be 'on the way'.

This respondent's certainty and commitment are very striking. He appears to be in command, and very much at home, when he is talking about his sector or his company and it is here, at work, that he feels himself to be creative. In his non-working life, however, he is less certain, and was clearly challenged personally during the crisis of his divorce. When asked how much he identifies with his father's life, he is reluctant to answer, saying that he considers this issue to be too intimate. He concedes, however, that he is slowly starting to 'think about it'. 
'I have contact ... Yes, yes, I have contact. Not too much, at the moment, I have contact with my father, with my brothers and sisters.'

In response to the question 'do you have the impression that your life is similar to your father's?' he answered,

'This is an exciting question, yes. An exciting question, and I am slowly starting to think about it. It is striking in many ways, but in the end, no, I believe, no, really not.'

For him, the job is the place where decisions are made, plans developed, and competences formed. Vital process, which are threatening when they cannot be calculated or manipulated, have to be rationalised, processed and integrated into this stringent professional concept in order to achieve a successful Allgemeine Lebensführung.

\section{The contradictions of dealing with a work-oriented life}

It is clear that, albeit in different ways, work is the central reference point in all these strategies, especially for women in the multimedia sector who identify with their fathers and see labour as the means of realising their own life models. The very different strategies of control, discipline, individual freedom, and stringency can be observed both for women and men but represent a much greater change of cultural and social patterns for the women, who have to overcoming their uneasiness with traditional patterns of femininity in adapting to a conception of labour that has traditionally been very masculine. Trying to reconcile high performance delivery at work with continuity in private life leads to considerable ambivalence and high friction losses for these women. Although they insist that children, partnerships and the social environment ultimately matter more to them than their jobs, their subjective identity formation nevertheless takes place mainly through work.

The most extreme is the control type in which not only are work processes themselves, and the working day itself, strictly regimented, but this control also extends to the vital and emotional processes of life. From an early age, general life is subjected to the standardised requirements of the job and decisions are made against open life processes in order to avoid unpredictable events.

The discipline type can be seen as representing the 'perfect woman', who 'manages' job, family, and partnership whilst still keeping her spirits high. Her way of life can only be safeguarded through tight organisational regulation and a disciplined time regime that encompasses the whole social environment, not just work, requiring strong individual effort .

For the individual freedom type, success or failure is attributed entirely to the individual's own efforts and individuality plays the dominant role in both work and private life. For this type it is also important to be able to control vital processes.

Although the stringency type is found to some extent in all the case studies, it is particularly common amongst men, whose attitude to success contrasts with that of the women interviewed. Whereas most women attribute their success to 'having been lucky' in their professional careers, for the men, success is something they are entitled to, so long as they pursue their goals with sufficient consistency.

With a few exceptions, the lives studied here can be described as 'strategic' in the sense that life is subjected to a purpose- and target-oriented perspective, which 
enhances 'the long-term tendency towards a growing rationalisation and self-discipline of the actors in society' (Kleemann et al. 1999:17). Because the change has taken place within a single generation, this tendency is particularly visible for the female interviewees, for whom it entails both gains and losses.

The main gain, which by all the women interviewed aspired to, may be described as 'access to social resources'. This access offers life models of individual autonomy guaranteed by economic independence and recognition as full members of society. Because men's and women's lives are interlinked, the uneasiness of these women with traditional gender roles affects both sexes, and their deviation from traditional roles affects many aspects of life including partnerships, education and the general design of life (BeckerSchmidt 1995).

The main losses can be seen in the need to adopt inflexible and rigid lifestyles. The domination of daily life by the structures of work had resulted in a suppression of vital processes for nearly all the women interviewed (the two exceptions, interestingly, were both women with children). The ability to maintain a successful lifestyle in the face of this pressure depends very strongly on the psychic dispositions and living conditions of the women. Achieving a sustainable work-life balance requires detachment from the original family, the development of life visions outside of the job, and stable emotional relationship structures. For the women interviewed, adopting the traditionally male labour model is rarely a matter for reflection and is generally seen as the only possible way of life.

These women regard 'performance' and 'efficiency' as the decisive factors in their professional careers and refuse to see themselves as women who are discriminated against or to see gender equality demands as relevant to their situations. Personal commitment and dedication are what matters for career development, in their view. No reattachment to or orientation towards traditional 'maternal worlds' was observed in any case study.

On the contrary, it is clear that everyday life is shaped by the structures of work, with time pressure, stress, and internalised feelings of tension spilling over into private life. To cope with these, it seems that aspects of 'efficiency' and 'quality assurance' have also started to enter general life, although the background of general tension makes it difficult to see the ways in which this leads to the control of relationship structures and the rationalisation of emotions. Relationships with partners and children are subjected to the breathless dictates of work demands and vital processes like ageing, individual affections, personal needs or events like illness or death among friends or family become threatening because they might shake the belief that everything is under individual control. Leisure and chances to stop and think are driven out by 'time pressure' and 'haste' resulting in some cases in morbid stress phenomena. A 'separated life' (BeckGernsheim 1993), a life based on labour, is not conflict-free, but gives rise to ways of life that must be assessed very differently from their traditional counterparts.

\section{The vitality of work - preliminary conclusions}

In order to be successful at work, these interviewees had to engage in a 'permanent balancing act' (Hielscher/Hildebrandt 1999) which made huge demands in terms of expertise, willpower, and individual time management. Work-related skills alone are 
not enough to meet these demands; the challenges of work have to be met with both 'body and soul.' ${ }^{14}$ This balancing act affects both men and women, who increasingly have to align their personal lives with the demands made on them by their employers, developing, as we have seen, a variety of strategies to achieve this. Whether the arrangements that result are considered to be enriching or burdensome can only be assessed within the context of each individual life.

The strategies of control and discipline illustrate the submission of living processes to the primacy of labour. The biological and social rhythms of life, the transmission of traditions, periods of rest and a huge range of non-market activities, such as gardening, intellectual activities or care for others, disappear under the relentless demands of the working day, leaving little or no time for social and political commitment, music or creative activities. Detached from many possibilities of life, these respondents have developed time regimes that reflect their compulsion (see also Boes \& Baukrowitz 2002, Boes \& Trinks 2005, Kahlert \& Kajatin 2004). The losses entailed in these processes are perceived and processed in a variety of ways but they are rarely, if ever, attributed to the conflicting social conditions under which these women live.

These findings confirm those from other studies within German industrial sociology, which have concluded that post-Taylorist business strategies are deeply ambivalent. On the one hand the new working conditions of the kind found in the multimedia sector offer workers autonomous working conditions with a considerable degree of independence. On the other, these conditions often result in an internalisation of the company's objectives and a self-economisation of the workforce. ${ }^{15}$ These 'bindings' directly influence their social and cultural references at several levels (Jürgens 2003, 2005).

There is an agreement between industrial sociology and feminist literature that the restructuring of work impacts the private sphere ${ }^{16}$. Polarisation around the issue of children is one clear indicator of this. In Germany in the past three decades, the proportion of lifestyles without children (at 65.3 per cent) has clearly overtaken those with children (at 33.9 per cent) (Manske 2003:141). This applies to both women and men but, as demonstrated in our study, it is the lives of working women that are especially affected by this.

'What this means [...] is obvious for men, who concentrate their social activities mainly on their professional careers. They are in danger of being caught in a

14 Sometimes described as the 'subjective dimension of work', this development combines two ways of using personnel resources: an increased use of subjective achievements in the organisation of work at the company; and extended access to the subjective potentials of working people (Baethge 1991, Kleemann, Matuschek, Voß 1999).

15 The term 'workforce entrepreneur' has been coined to describes the phenomenon whereby employees assume responsiblity for the results of their activities and reaching their objectives, having to translate requirements into decisions and work processes and take responsibility if the goals are not met. Elements of the role of the entrepreneur are transferred to the employees; self-control, self-economisation, and identification with the company become central (Voß, Pongratz 1998, Voß 2002, Pongratz, Voß 2003). For an overview of feminist criticism of this approach see Aulenbacher, 2005.

16 Gender research has observed the development of new lines of differentiation among employees in such new work cultures. Whereas gender is relativised in the case of young, qualified women without children, other women - mainly due to the reduction of social security offered by the state - are exposed more than ever to the double burden of family and job. Strong integration into labour structures magnifies the impact of unforeseen occurrences. As a result, criteria such as the age of employees gain in importance (Aulenbacher 2005). 
rationalisation trap: the lack of mental, emotional, and sensory experience that is gained in the psycho-social field of household and private supplies

[...] may freeze the lively capacity for work.' (Becker-Schmidt 2003:105)

It is clear that women in highly skilled professions have gained social recognition, economic independence, and social autonomy and these have had an immediate effect on the structures of their sexual relationships, on lifestyles and on women's broader social relationships. However a look at the other side of this coin discloses states of deep exhaustion, permanent hurry, and feelings of loss, suggesting that the price of this successful professional integration is a sacrifice of the 'lively' areas of private life.

From the perspective of gender research, this raises questions about gender and the new work cultures. Women have been integrated successfully into certain sectors of qualified employment, especially highly-skilled services where they have a strong presence, at least below the management level (Nickel 2004, Lohr \& Nickel 2005, Manske 2003, Kocyba 2005) and have repeatedly demonstrated their willingness to adapt to company requirements for high flexibility and mobility and adjust their lives to meet these demands. This does not only apply in the IT sector, but also in other service companies such as banks and consultancies where women have been relatively well positioned since the mid 1990s. These jobs have not only given them economic security but have also opened up opportunities for self-realisation and professional self-development, as is demonstrated in the cases presented here. Communicative, creative, and expressive aspects of work have gained in importance compared with traditional job cultures ${ }^{17}$.

But, despite the positive features of these developments, there is a need for careful study at an individual level of how these losses are perceived by the women affected and what impact they have had on their daily lives. This study suggests that the gains and losses resulting from changing working and living conditions are complex and ambiguous and will have to be analysed in a way that makes visible the contradictory social relationships that lead to these gains, losses and paradoxes. What is clear is that they are experienced with 'mixed feelings' (Becker-Schmidt 2003:118).

The study also supplies some evidence of a tendency towards rationalising the private world, observed in a more acute form in a US study by Arlie Russell Hochschild who found that the office is increasingly being perceived as 'home' whilst the home is experienced as a place where work is always waiting (Russell Hochschild 2006) ${ }^{18}$. It can be concluded that a highly effective work culture has given rise to an internalised compulsion to work more efficiently and permanently and produced a situation in which the reproductive sphere becomes a threat to the capacity to work in this way (Voß 2003:331, Oechsle 2006).

17 Kocyba points out that dependent labour 'sells' its own work capacity (and not the product of the work). 'For the seller in this workforce, this means that, whatever the activity he is asked to do may look like, he can hardly understand it as a self-realisation in the sense of reaching the targets set by himself' (Kocyba 2005:141).

18 Russell Hochschild also mentions the 'double socialisation' (Becker-Schmidt) of women in the company she studied. This is typified by a high commitment that is not usually gratified, 'whereas men with their experienced refusal of requirements possibly may not make a career, but still get a safe employment and/or may be with the family or think of leisure time, if they wish' (Aulenbacher 2005:51). 
Here, as gender research has pointed out, it is relevant to look at the relationship between the productive and reproductive spheres in society which, though separated, are still inter-related in terms of how they are recognised or devalued. In this study, a strong orientation towards the father's life model was associated with a lack of social recognition of maternal worlds, demonstrating that there is a lack of models in which the life and work of working men and women are in balance ${ }^{19}$.

It was also observable that the decision not to have children does not release women from the simultaneous experience of both gains and losses in their lives. This ambivalence between conflicting value spheres (care, nurture, and social integration on the one hand, and autonomy and independence on the other) constitutes a 'rationalisation of female behaviour in the private sphere' (Illouz 2006:51). ${ }^{20}$ As illustrated in this study, these rationalisations are derived from a range of different individual needs and attitudes. Nevertheless, it is obvious that the integration of women into this type of market-oriented labour is in clear conflict with private life, which, at a societal level, has the task of maintaining and renewing not only the workforce, but human life itself. So far, very little scholarly attention has been paid to what this means concretely for the individual or for society as a whole. This omission is dangerous, because a new balance between life and work is necessary to address a range of urgent social problems, including the creation of jobs, the globalisation of labour and, at least in Germany, the falling birth-rate. The social integration of maternal worlds into the lifestyles of both men and women is a necessary precondition for this.

'When looking for tasks to keep the work of women and men lively, strong visions are needed. Work cannot only be found in the sphere of necessity. It contributes to celebration, to strengthening relationships, to hospitality and to enjoying nice things. This has to be included in life.' (Becker-Schmidt 2003:128ff)

\section{(C) Bettina-Johanna Krings, 2006}

\section{REFERENCES}

Allmendinger, J. \& A. Podsiadlowski, (2001) 'Segregation in Organisationen und Arbeitsgruppen', Heintz, B. (ed.) Geschlechtersoziologie, Wiesbaden: Westdeutscher Verlag:276-307 Alltägliche Lebensführung (ed.) (1995) Alltägliche Lebensführung. Arrangements zwischen Traditionalität und Modernisierung, Redaktion: W. Kuderas, S. Dietmaier, \& S. Opladen: Leske \& Budrich Aulenbacher, B. (2005) 'Subjektivierung von Arbeit. Ein hegemonialer industriesoziologischer Topos und was die feministische Arbeitsforschung und Gesellschaftsanalyse dazu zu sagen haben', Lohr, K \& H. Nickel, Subjektivierung von Arbeit - Riskante Chancen, Münster: Westfälisches Dampfboot:34-64 Baethge, M. (1991) 'Arbeit, Vergesellschaftung, Identität - Zur zunehmenden normativen Subjektivierung der Arbeit', Soziale Welt, H 42/1991:6-19

Baukrowitz, A.\& A.Boes (2002) Arbeitsbeziehungen in der IT-Industrie. Erosion oder Innovation der Mitbestimmung?, Berlin: edition Sigma 55 Jg.:10-18

Baukrowitz, A. \& A. Boes(1996) 'Arbeit in der 'Informationsgesellschaft' - einige Überlegungen aus einer (fast schon) ungewohnten Perspektive', Schmiede, R. (ed.) Virtuelle Arbeitswelte, Berlin: edition

19 The discussion of work-life balance covers a number of issues, including the working time regime, family research, family policy, future work models and other related issues (cf. Oechsle 2006, Metz-Göckel 2004). 20 This rationalisation represents a process of clearance and disclosure of personal values and preferences. 'What do I want? What do I need? Am I adventurous or do I need security?' This process is successful when the women observe themselves, control their emotions, assess their decisions, and take the direction selected. In this way, numerous life models are generated, which end up becoming cultural forces of change' (Illouz, 2006). 
Baukrowitz, A., A.Boes \& B. Eckhardt(1998) 'Veränderungstendenzen der Arbeit im Übergang zur Informationsgesellschaft - Befunde und Defizite der Forschung', Enquete-Kommission Zukunft der Medien, a.a.O:13-170

Baukrowitz, A. \& A.Boes (2001) 'Bewegung in den Arbeitsbeziehungen - Das wandlungsfähige deutsche System passt unterschiedlich gut', Die Mitbestimmung, H 6:42-45

Bechmann, G. G. Frederich \& B-J. Krings (1999) Information Society, Work and the Generation of New Forms of Social Exclusion (SOWING), Regional Report for Germany, Karlsruhe: Forschungszentrum Karlsruhe

Bechmann, G. G. Frederich \& B-J. Krings (2001) Information Society, Work and the Generation of New Forms of Social Exclusion (SOWING), Final National Report, Germany, Karlsruhe: Forschungszentrum Karlsruhe

Beck, U. (1986) Die Risikogesellschaft, Frankfurt/M.: Suhrkamp

Beck-Gernsheim, E. (1993) Das halbierte Leben, Frankfurt/M.: Fischer

Becker-Schmidt, R. (1995) 'Von Jungen, die keine Mädchen und von Mädchen, die gerne Jungen sein wollten. Geschlechtsspezifische Umwege auf der Suche nach Identität', in: Becker-Schmidt, R. \& G-A. Knapp (eds.) Das Geschlechterverhältnis als Gegenstand der Sozialwissenschaften, Frankfurt/M./New York: Campus, S. 220-246

Becker-Schmidt, R. (2003) 'Umbrüche in Arbeitsbiographien von Frauen: Regionale Konstellationen und globale Entwicklungen', in: Knapp, G-A. \& A.Wetter(eds.) Achsen der Differenz. Gesellschaftstheorie und feministische Kritik II, Münster: Westfälisches Dampfboot:101-132. Behringer, L. (1998) Lebensführung als Identitätsarbeit. Der Mensch im Chaos des modernen Alltags, Frankfurt/M.; New York: Campus

Boes, A. (1996) 'Formierung und Emanzipation. Zur Dialektik der Arbeit in der "Informationsgesellschaft"', Schmiede, R. (eds.) Virtuelle Arbeitswelten. Arbeit, Produktion und Subjekt in der 'Informationsgesellschaft', Berlin: edition Sigma:159-178

Boes, A \& K. Trinks (2005) 'Interessen und Interessenhandeln von IT-Beschäftigten in der Genderperspektive', Funder, M.S. Dörhöfer \& C. Rauch (eds.) Jenseits der Geschlechterdifferenz? Geschlechterverhältnisse in der Informations- und Wissensgesellschaft, München und Mering: Rainer Hampp Verlag:284-304

Boß, C. \& V. Roth (1992) Die Zukunft der DV-Berufe, Opladen: Westdeutscher Verlag Castells, M. (1996) The Rise of the Network Society, Malden, USA; Oxford,UK: Blackwell Datenreport (2002) Zahlenreport für die Bundesrepublik Deutschland, Bonn: Bundeszentrale für politische Bildung

Fuchs, G \& H.G.Wolf (1998a) Multimedia Unternehmen in Baden-Württemberg: Erfahrungen, Erfolgsbedingungen und Erwartungen, Arbeitsbericht Nr. 128 der Akademie für Technikfolgenabschätzung in Baden-Württemberg, Stuttgart

Fuchs, G.\& H.G.Wolf (2000) Regionale Erneuerung durch Multimedia?, Baden-Baden: Nomos Funder, M. (2005) 'Gendered Management? Geschlecht und Management in wissensbasierten Organisationen', in: Funder, M., S. Dörhöfer \& C. Rauch, (eds.) Jenseits der Geschlechterdifferenz? Geschlechterverhältnisse in der Informations- und Wissensgesellschaft, München \& Mering: Rainer Hampp Verlag:97-122

Gottschall, K. \& G.G.Voß (2005) Entgrenzung von Arbeit und Leben. Zum Wandel der Beziehung von Erwerbstätigkeit und Privatsphäre im Alltag, München: Rainer Hampp Verlag

Harding, S. (1990) Feministische Wissenschaftstheorie. Zum Verhältnis von Wissenschaft und sozialem Geschlecht, Hamburg: Argument-Verlag

Hielscher, V. \& E. Hildebrandt (1999) Zeit für Lebensqualität. Auswirkungen verkürzter und flexibilisierter Arbeitszeiten auf die Lebensführung, Berlin: edition sigma

Illouz, E. (2006) Gefühle in Zeiten den Kapitalismus, Frankfurt/M.: Suhrkamp

Jürgens, K. (2003) 'Die Schimäre der Vereinbarkeit. Familienleben und flexibilisierte Arbeitszeiten', Zeitschrift für Soziologie der Erziehung und Sozialisation, 23 (3):251-267

Jürgens, K. (2005) 'Kein Ende von Arbeitszeit und Familie', Arbeitszeit - Familienzeit - Lebenszeit. Zeitschrift für Familienforschung, Sonderheft 5, Wiesbaden:165-183

Jurcyk, K.\& M. Rerrich (eds.) (1993) Die Arbeit des Alltags. Beiträge zu einer Soziologie der all- 
täglichen Lebensführung, Freiburg, Br.: Herder

Kahlert, H \& C. Kajatin (eds.) (2004) Arbeit und Vernetzung im Informationszeitalter, Frankfurt, M.; New York: Campus

Kleemann, F., I. Matuschek \& G.G, Voß (1999) Zur Subjektivierung von Arbeit, Veröffentlichung der Querschnittsgruppe Arbeit\&Ökologie beim Wissenschaftszentrum Berlin:99-512

Kocyba, H. (2005) 'Selbstverwirklichung im Unternehmen - Chance als Anerkennungsfalle?', Funder, M., S. Dörhöfer, S \& C. Rauch. (eds) Jenseits der Geschlechterdifferenz? Geschlechterverhältnisse in der Informations- und Wissensgesellschaft, München \& Mering: Rainer Hampp Verlag:139-153

Kratzer, N. (2003) Arbeitskraft in Entgrenzung. Grenzenlose Anforderungen, erweiterte Spielräume, begrenzte Ressourcen, Berlin: edition Sigma

Krings, B-J. (2003) Wandel der Arbeits- und Lebensbedingungen im Multimediabereich aus der Genderperspektive, Wissenschaftliche Berichte FZKA 6892, Karlsruhe: Forschungszentrum Karlsruhe Lohr, K. \& H.M. Nickel(2005) 'Subjektivierung von Arbeit - Riskante Chancen', in: Lohr, K.\& H.M. Nickel(eds.) Subjektivierung von Arbeit - Riskante Chancen, Münster: Westfälisches Dampfboot: 207-232

Manske, A. (2003) 'Web Worker. Arrangements der Sphären im Spannungsfeld von Vereinnahmung und Ergänzung', Gottschall, K. \& G.G. Voß (eds.) Entgrenzung von Arbeit und Leben, München \& Mering: Rainer Hampp Verlag, S. 261-282, 2. Auflage 2005

Manske, A. (2003) 'Arbeits- und Lebensarrangements in der Multimediabranche unter Vermarktlichungsdruck - Rationalisierungspotenzial für den Markterfolg?', Kuhlmann, E. \& S. Betzelt(eds.) Geschlechterverhältnisse im Dienstleistungssektor. Dynamiken, Differenzierungen und neue Horizonte, Baden-Baden: Nomos:133-146

Menez, R., I. Munder, I. \& K.Töpsch (2001) Qualifizierung und Personaleinsatz in der IT-Branche, Auswertung der Online-Studie BIT-S, Arbeitsbericht der Akademie für Technikfolgenabschätzung Nr. 200, Stuttgart

Metz-Göckel, S. (2004) 'Wenn die Arbeit die Familie frisst: Work Life Balance ein Genderproblem?', Kastner, M. (ed.) Die Zukunft der Work Life Balance. Wie lassen sich Beruf und Familie, Arbeit und Freizeit miteinander vereinbaren?, Kröning: Asanger, S. 107-139

Minssen, H. (ed.) (1999) Begrenzte Entgrenzungen. Wandlungen von Organisation und Arbeit, Berlin: edition Sigma

Nickel, H. M. (2004) Zukunft der Arbeit aus feministischer Perspektive', in: Baatz, D., C.

Rudolph, C. \& A. Satilmis (eds.) Hauptsache Arbeit? Feministische Perspektiven auf den Wandel von Arbeit, Münster: Westfälisches Dampfboot:242-254

Nordhause-Janz, J \& D. Rehfeld (1999) 'Informations- und Kommunikationswirtschaft Nordrhein-Westfalen', Institut Arbeit und Technik (ed.), Graue Reihe des Instituts Arbeit und Technik, Band 1. Gelsenkirchen

Oechsle, M. (2006) Deutschland in der Zeitfalle? Zur Rezeption von Arlie Russel Hochschilds 'Keine Zeit' in Deutschland, Einleitung in Russell Hochschild a.a.O.:VII-XIX

Oevermann, U. (1978) Probleme der Professionalisierung in der berufsmäßigen Anwendung sozialwissenschaftlicher Kompetenz, Frankfurt/ M. (unpublished manuscript)

Pongratz,H. J. \& G.G. Voß (2003) Arbeitskraftunternehmer. Erwerbsorientierungen in entgrenzten Arbeitsformen, Berlin: edition Sigma

Priddat, B. (2001) Frauen als virtuelle Unternehmerinnen: hyper organisations of work, life and household, Ein Beitrag zur Geschlechterfrage der New Economy, Witten: Verlag Witten Russell Hochschild, A. (2002) Keine Zeit. Wenn die Firma zum Zuhause wird und zu Hause nur Arbeit wartet, Wiesbaden: VS-Verlag, 2. edition 2006

Voß, G.G. (1991) Lebensführung als Arbeit. Über die Autonomie der Person im Alltag der Gesellschaft, Stuttgart: Enke

Voß, G.G. (1998) 'Die Entgrenzung von Arbeit und Arbeitskraft. Eine subjektorientierte Interpretation des Wandels der Arbeit', Mitteilungen aus der Arbeits- und Berufsforschung, 31 (3):473-487

Voß, G.G. (2003) 'Entgrenzte Arbeit - Gestresste Familien', in: Zeitschrift für Familienforschung, 15. Jg., H 3/2003:329-335 
Voß, G.G.\& H.J.Pongratz (1998) 'Der Arbeitskraftunternehmer. Eine neue Grundform der Ware Arbeitskraft?', in: Kölner Zeitschrift für Soziologie und Sozialpsychologie, Jg. 50, H1:131-158

Wohlrab-Sahr, M. (1993) Biographische Unsicherheit. Formen weiblicher Identität in der 'reflexiven Moderne': Das Beispiel der Zeitarbeiterinnen, Opladen: Leske + Budrich

Zwick, M.\& O. Renn (2000) Die Attraktivität von technischen und ingenieurswissenschaftlichen

Fächern bei der Studien- und Berufswahl junger Frauen und Männer, Stuttgart: Akademie für Technikfolgenabschätzung in Baden-Württemberg

\section{ACKNOWLEDGEMENTS}

I would like to thank Linda Nierling (ITAS), the anonymous peer reviewers, and Ursula Huws for their extremely constructive comments on the first draft of this paper. 